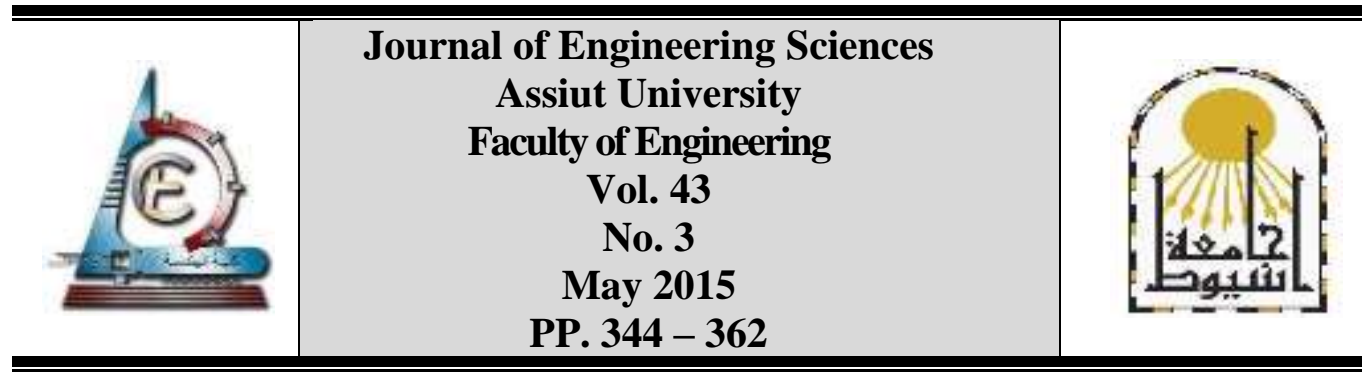

\title{
A MODIFIED PERTURB AND OBSERVE ALGORITHM FOR MAXIMUM POWER POINT TRACKING OF PHOTOVOLTAIC SYSTEM USING BUCK-BOOST CONVERTER
}

\author{
Adel A. Elbaset ${ }^{1}$, Hamdi Ali ${ }^{2}$, Montaser Abd-El Sattar ${ }^{*}, 3$ \\ ${ }^{l}$ Department of Electrical Engineering, Minia University, El-Minia, 61517, Egypt \\ ${ }^{2,3}$ Dept. of Electrical and Computer Eng., El-Minia High Institute for Eng. and Technology, El-Minia, Egypt
}

(Received 23 February 2015; Revised 1 May 2015; Accepted 14 May 2015)

\begin{abstract}
Perturb and Observe (P\&O) maximum power point tracking (MPPT) algorithm is widely applied due to its simplicity, costless and easy implementation. However, $\mathrm{P} \& \mathrm{O}$ tracking algorithm suffers from drift or instabilities due to change of irradiance, and oscillation around maximum power point (MPP) at steady state. Drift occurs due to the incorrect decision taken by the conventional P\&O algorithm at the first step change in duty cycle during the change in irradiance. This paper modifies conventional $\mathrm{P} \& \mathrm{O}$ algorithm to overcome these drawbacks and improve MPPT performance of photovoltaic (PV) system and DC/DC converter to supply a resistive load under rapidly change of weather conditions. This modified technique is proposed to avoid the problem of irradiance variation by incorporating the information of voltage, current and power in the decision process for updating the duty cycle of the converter. Simulation results of the proposed algorithm achieved minimum power oscillations with high accuracy, better dynamic response and stability for changes of irradiance, load and temperature. The obtained results are compared with the previous experimental results which are obtained in the literature.
\end{abstract}

Keywords: Photovoltaic (PV) system; Maximum power point tracking (MPPT); Perturb and Observe $(P \& O)$ algorithm.

\section{Introduction}

Recently, the field growth of photovoltaic (PV) system market is increased because of its benefits such as availability in everywhere, abundant, costless maintenance and eco-friendly nature [1]-[2]. Although PV system has many benefits, it faces three major problems. One of them is the lowering of its efficiency that can be hardly reached up to $20 \%$ for multicrystalline modules, while the two others are the changing of the electric power with weather variations and non-linearity of their electrical characteristics. The lowering of efficiency is coming from manufacturing techniques and weather conditions. Normally, the efficiency of the PV system mainly depends on the operating point on the characteristic curves of the PV

\footnotetext{
* Corresponding author.

E- mail address:mymn2013@yahoo.com
} 
module [2]-[6]. These characteristic curves will alter with solar irradiance level and atmospheric temperature [1]. The PV system should be operated at a maximum power point (MPP) which is normally unique point on the P-V curve to obtain the highest efficiency. This point varies its location as a result change of weather conditions [6]-[8].

Maximum power point tracking (MPPT) represents the important algorithm that should be included in every PV system to satisfy the highest efficiency. It is an electronic controlled system intended to monitor the terminal voltage/current of the PV system for extracting the MPP. This is done by adjusting the duty cycle of a DC/DC converter that matches the output load with source impedance of the PV system. Normally, the optimal MPPT should track MPP at all times whatever the weather conditions or load variations are being. It also should be simple, accurately and implemented economically [5], [9]-[10].

Until now a numerous of MPPT techniques have been developed [11]-[33] to increase the efficiency of the PV system and satisfy the optimal MPPT. These techniques vary in various aspects such as tracking speed, oscillations around MPP, cost, and hardware required for implementation. Most famous MPPT algorithms available are such as fractional open circuit voltage [11], fractional short circuit current [11], Hill-climbing (HC) [6], [12], perturb and observe (P\&O) [13]-[20], incremental conductance (IncCond) [21]-[25], incremental resistance (INR) [26], ripple correlation control (RCC) [27], fuzzy logic (FL) [28], artificial neural networks (ANN) [29], particle warm optimization (PSO) [18], [30]-[31], and sliding mode [32]-[33]. Overview of various MPPT techniques are discussed in [34]-[37].

Among all mentioned methods, the $\mathrm{P} \& \mathrm{O}$ algorithm is the most popular and widely used due to its simplicity, ease of implementation and low cost. However the algorithm fails tracking MPP during rapid change of weather and its tracking performance has steady state oscillations around MPP according to step size [6]-[7], [13], [18]. Ref. [13] has applied a constraint on perturbation step size $(\Delta D)$ to enable conventional $P \& O$ algorithm to overcome the deviation from MPP or instability problem due to rapid variation of weather. Although the modification successes to track MPP under rapid change of weather, a higher value of step size $(\Delta \mathrm{D})$ causes high power losses in steady state. Ref. [15] suggested maximum and minimum threshold value of power change $(\Delta \mathrm{P})$ to overcome the previous problem. This suggestion is not optimal solution due to constraints on power change that is depends mainly on weather conditions. Entire trend of P-V curve was proposed by Ref. [16] to solve such problem, but it is not practical in case of a rapid change of weather as the operating point moves into the new point on the corresponding irradiance P-V curve for each irradiance change. Ref. [1] suggested the positive sign of current change $(\Delta \mathrm{I})$ to avoid the problem, but this solution is only for increasing of irradiance, and lacking information about rapid decreasing of weather.

Although conventional $\mathrm{P} \& \mathrm{O}$ has remarkable advantages and many research modified it, the oscillation problem and tracking of MPP under rapid change of weather are still challenging problems [1], [6] - [7], [18]. This paper presents an accurate and simple solution to enable conventional $\mathrm{P} \& \mathrm{O}$ algorithm to track MPP under rapid change of weather (either increasing or decreasing) and minimizing its oscillation. The steady stated oscillation is reduced by choosing a linear variable " $\mathrm{d}$ " between input and output voltages 
Montaser Abd-El Sattar, et al., A modified perturb and observe algorithm for maximum power...

of the DC/DC buck-boost converter that is result smoothing change of duty cycle " $\mathrm{D}$ ". The minimizing oscillations are satisfied with fast tracking of MPP at the same time.

\section{Conventional perturb and observe algorithm}

Conventional $\mathrm{P} \& \mathrm{O}$ algorithm is the simplest, costless, popular and almost applicable in practice with efficiency up to $96.5 \%$ [3]. However, it is not robust in tracking the right MPP at rapid changes of weather [6], [13], [18], [38]. The algorithm obtains its information from the actual operating point of the PV module or array (i.e., voltage, $\mathrm{V}_{\mathrm{pv}}$ and current, $\mathrm{I}_{\mathrm{PV}}$ ) to scan the P-V curve in order to obtain MPP as shown in Fig. 1. The scanning of the P-V curve is done by changing the operating point $\left(\mathrm{V}_{\mathrm{PV}}\right.$ or $\left.\mathrm{I}_{\mathrm{PV}}\right)$, which is known as perturbation step, and then measuring the change in PV power $(\Delta \mathrm{P})$, that is known as observation step. The resulting change of PV power is observed as follow [1], [38]:

- If $\frac{\Delta \mathrm{P}}{\Delta \mathrm{V}}$ is positive, the perturbation of voltage should be increased from point "A" towards MPP as shown at the left side of Fig. 1.

- If $\frac{\Delta \mathrm{P}}{\Delta \mathrm{V}}$ is negative, the perturbation of voltage should be decreased from point "B" towards MPP as shown at the right side of Fig. 1.

- The previous process is repeated until is reached to MPP where $\frac{\Delta \mathrm{P}}{\Delta \mathrm{V}}$ is closely to zero; this is satisfied condition is called steady state.

- The P\&O keeps perturbing the system in order to detect a change in the MPP (caused by a change in the environmental conditions or load), which triggers a new scan.

Normally, this process causes the operating point of the PV system to oscillate around MPP. The flowchart of conventional P\&O algorithm is shown in Fig. 2 [38].

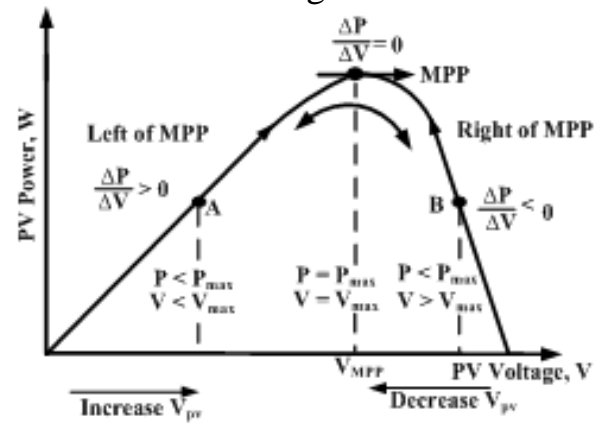

Fig. 1. Perturb and observe on P-V curve.

\subsection{Conventional perturb \& observe algorithm and weather variations}

\subsubsection{Rapid change of irradiance}

The successive rapid increasing of irradiance causes drift or instability problem due to conventional $\mathrm{P} \& \mathrm{O}$ algorithm is unable to recognize the increase in power either is coming from weather or perturbation change. Suppose there is an increase in irradiance level from (400-800) W/m ${ }^{2}$, whiles the PV system operates at point MPP1 at perturbation $\mathrm{K}$ as shown in Fig. 3 then, the operating point will be moved to a new point 2 in corresponding irradiance curve during the same perturbation $\mathrm{K}$ which results positive change in both power $(\Delta \mathrm{P})$ and voltage $(\Delta \mathrm{V})[13],[34],[39]-[41]$. The information of positive change during perturbation $\mathrm{K}+1$ will make algorithm to increase voltage perturbation instead of decreasing and move operating point from point 2 to point 3 as shown in Fig. 3. This 
wrong decision causing the operating point of PV system is far away from MPP as a result of successive change of weather as shown in Fig. 3. Also, the successive rapid decreasing of irradiance will deviate the operating point of PV system away from MPP as discussed in Ref. [2]. The simulation result of Ref. [2] is shown in Fig. 4.

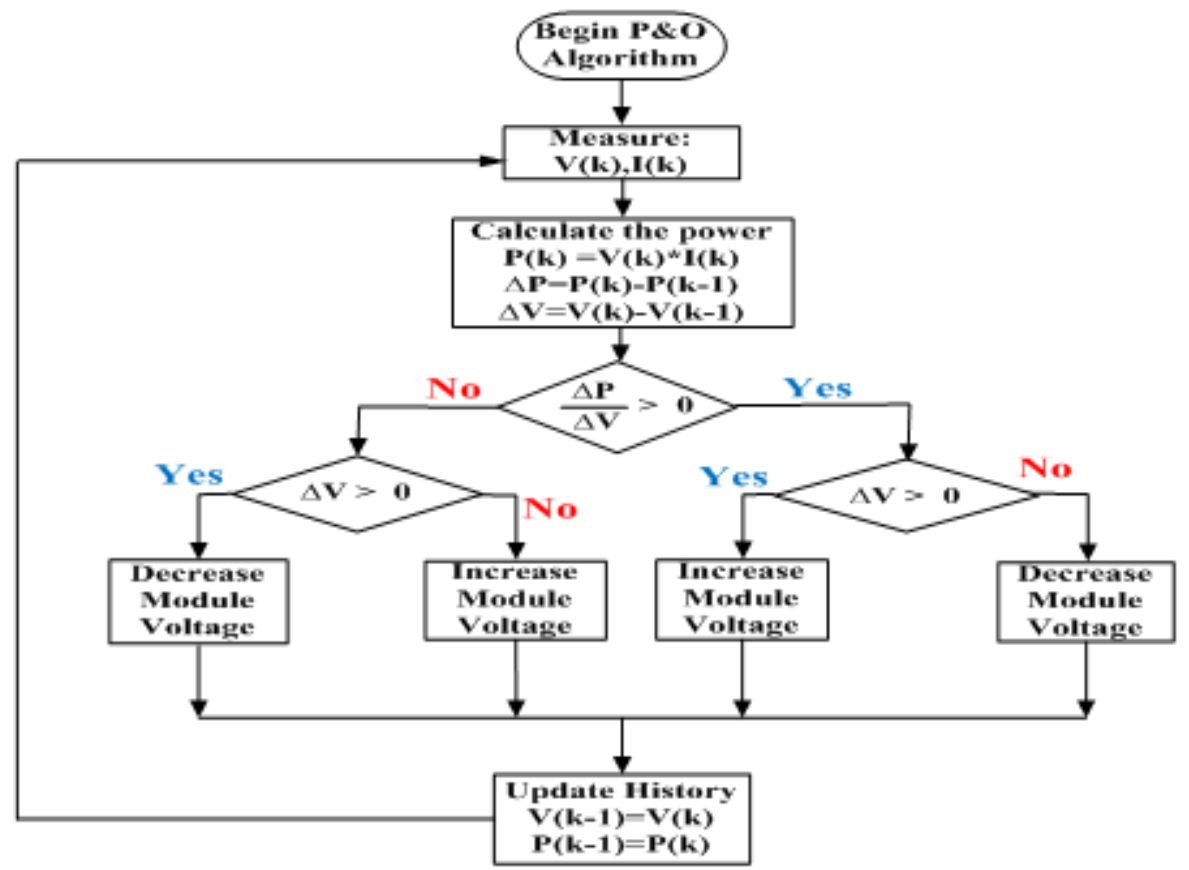

Fig. 2. Flowchart of conventional $\mathrm{P} \& \mathrm{O}$ algorithm [38].

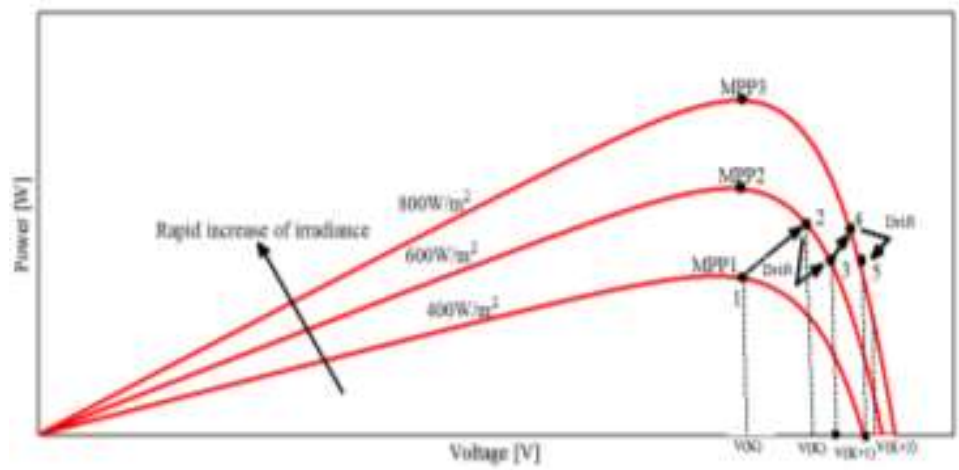

Fig. 3. Simulation results of rapid change in irradiance (increasing).

\subsubsection{Steady change of weather}

The steady change of weather will cause wrong decision of $\mathrm{P} \& \mathrm{O}$ algorithm at first perturbation as discussed in rapid change of weather, but the next perturbation will correct this wrong action. Suppose increasing in irradiance level from $(600-800) \mathrm{W} / \mathrm{m}^{2}$ and the PV system operates at MPP1 as shown in Fig. 5. The result of increasing PV power and voltage will increase perturbation voltage and consequently will divert the operating point from MPP2 at point 2 as shown in Fig. 5. The next perturbation at the same curve -without 
Montaser Abd-El Sattar, et al., A modified perturb and observe algorithm for maximum power...

weather change- is the negative change in PV power $(\Delta \mathrm{P}<0)$ and the positive change in $\mathrm{PV}$ voltage $(\Delta \mathrm{V}>0)$ will decrease the voltage perturbation towards MPP2 with subsequent next perturbations as shown in Fig. 5.

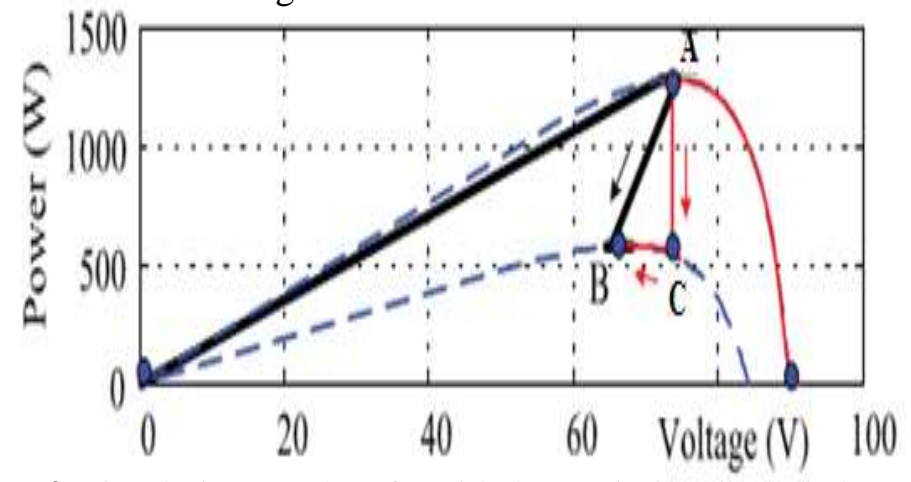

Fig. 4. Simulation results of rapid change in irradiance (decreasing).

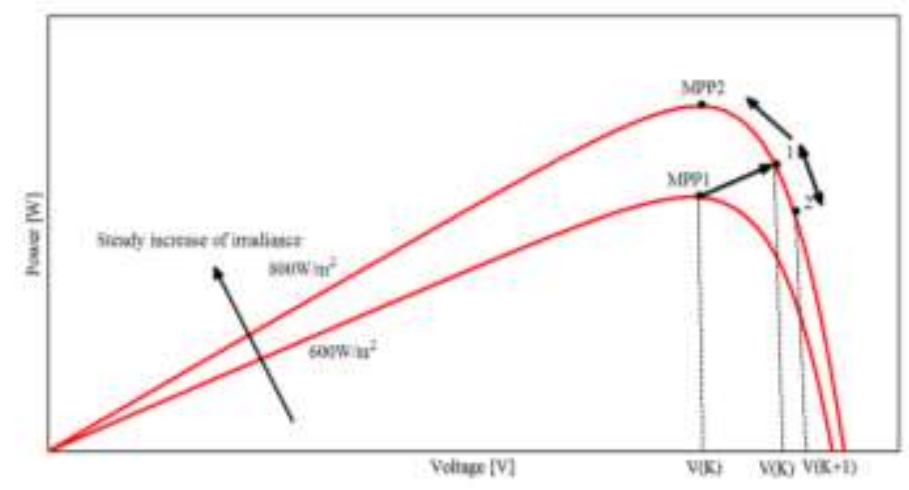

Fig. 5. Simulation results of steady change in irradiance.

\subsection{Conventional perturb \& observe algorithm and load change}

The photovoltaic load $\left(\mathrm{R}_{\mathrm{L}}\right)$ is connected across PV terminal via DC/DC buck-boost converter as shown in Fig. 6. The DC/DC buck-boost converter is intended to match the load impedance with source impedance of the PV system to satisfy maximum power transfer. Also, P\&O MPP tracker is used to enable the PV system to operate at MPP. The relations between input and output variables of DC/DC buck-boost converter are expressed as follow [1]-[2], [13], and [38]:

$$
\begin{aligned}
& \mathrm{V}_{\text {out }}=-\mathrm{d} * \mathrm{~V}_{\mathrm{PV}} \\
& \mathrm{I}_{\text {out }}=-\mathrm{I}_{\mathrm{PV}} / \mathrm{d} \\
& \mathrm{d}=\mathrm{D} /(1-\mathrm{D}) \\
& \mathrm{S}_{\mathrm{L}}=\mathrm{I}_{\mathrm{PV}} / \mathrm{V}_{\mathrm{PV}}=\mathrm{d}^{2}\left(\mathrm{I}_{\text {out }} / \mathrm{V}_{\text {out }}\right)=\mathrm{d}^{2} / \mathrm{R}_{\mathrm{L}} \\
& \mathrm{R}_{\mathrm{L}}=\mathrm{d}^{2}\left(\mathrm{~V}_{\mathrm{PV}} / \mathrm{I}_{\mathrm{PV}}\right)
\end{aligned}
$$

Where:

$\mathrm{V}_{\text {out }}, \mathrm{I}_{\text {out }}$ are output voltage and current of DC/DC buck-boost converter;

$\mathrm{V}_{\mathrm{PV}}, \mathrm{I}_{\mathrm{PV}}$ are voltage and current of PV system,

$\mathrm{d}$ is a linear control variable between $\mathrm{V}_{\text {out }}$ and $\mathrm{V}_{\mathrm{PV}}$, 
$\mathrm{D}$ is the duty cycle,

$\mathrm{S}_{\mathrm{L}}$ is the slope of load line, and

$\mathrm{R}_{\mathrm{L}}$ is the output load resistance of DC/DC buck-boost converter.

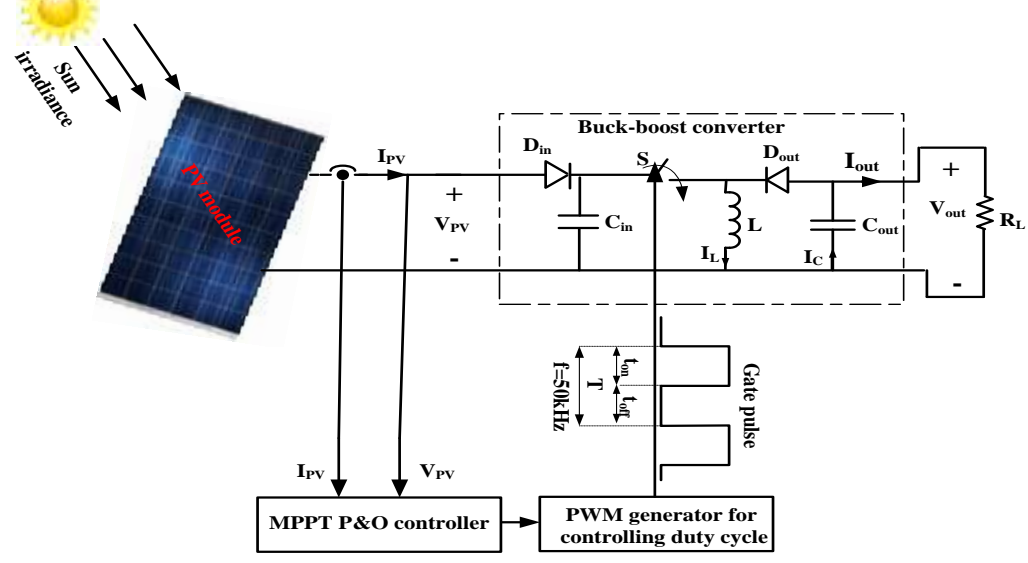

Fig. 6. Block diagram of PV system with MPPT control.

The operating point of the PV system is determined by the slope of load line as shown in Fig. 7 which normally is directly proportional with squared of controlled variable "d" and inversely proportional with load resistance " $\mathrm{R}_{\mathrm{L}}$ ". This slope will change the operating point on I-V characteristic curve of the PV system by changing linear variable " $\mathrm{d}$ " or load resistance. The algorithm will take this variable as controlled variable for voltage change and then computes the duty cycle from Eq. (3) as follow:

$\mathrm{D}=\mathrm{d} /(1+\mathrm{d})$

Normally, the PV system operates closed to MPP at steady weather and without change in load as shown in Fig. 7. The load change causes the operating point of the PV system to move away- either right or left side- from MPP at point $b$ of Fig. 7. The increasing in load resistance from $\mathrm{R}_{\mathrm{L} 1}$ to $\mathrm{R}_{\mathrm{L} 2}$ will move the operating point to the right side of MPP that is causing decrease in power and increase in voltage. The negative change in $\mathrm{PV}$ power $(\Delta \mathrm{P}<0)$ and positive change in PV voltage $(\Delta \mathrm{V}>0)$ will decrease the perturbation voltage as illustrated from flowchart of Fig. 2 [38], [41]. The positive change in power and negative change in voltage in subsequent perturbation will decrease the voltage at the same direction to MPP. Also, the decreasing of load resistance from $\mathrm{R}_{\mathrm{L} 1}$ to $\mathrm{R}_{\mathrm{L} 3}$ will move the operating point to the left side of MPP at point $c$ of Fig. 7. This action will cause negative change in both power and voltage that are causing the algorithm to increase the PV voltage towards MPP [1].

\subsection{Problem description of conventional perturbs and observe algorithm}

It is obviously from the previous explanation that the conventional $\mathrm{P} \& \mathrm{O}$ algorithm is taking wrong decision at first step of weather change that is accumulated with successive change of irradiance. The P\&O algorithm confused its direction towards the MPP due to lack its information about the cause of power change either is coming from weather 
variation or perturbation step due to load change. Also, the steady state oscillation is due to compromise between step size and tracking speed of MPP. Also, it is noticed that, there is no wrong decision or correction due to load change at steady weather. This means that the best performance of conventional $\mathrm{P} \& \mathrm{O}$ is for load change at steady weather.

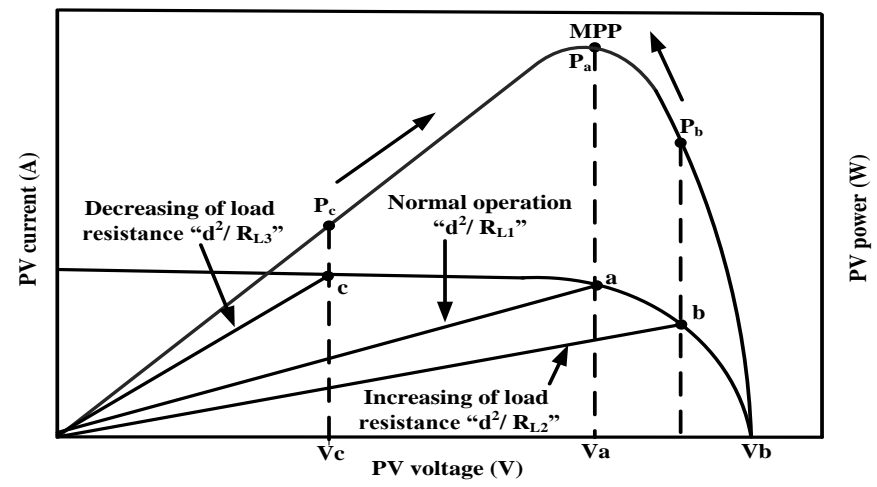

Fig. 7. Change of operating point with respect to load resistance $\left(R_{L}\right)$.

\section{Modification of conventional perturbs and observe algorithm}

\subsection{Basic modification}

The performance of conventional $\mathrm{P} \& \mathrm{O}$ algorithm as a result of the above discussions can be divided into weather change under constant load and load change under constant weather. The conventional $\mathrm{P} \& \mathrm{O}$ algorithm has best performance with load change, while has poor performance with weather change. To enhance the performance of conventional P\&O algorithm due to weather change under constant load $\left(\mathrm{R}_{\mathrm{L}}\right)$, it should be recognized this condition during rapid change or steady change of weather by computing load value $\left(R_{L}\right)$ in every perturbation step to ensure unchangeable of load and the change in power is coming from weather change. Also, the load change $\left(\Delta \mathrm{R}_{\mathrm{L}}\right)$ is done under constant weather conditions.

\subsection{Modification procedures due to weather change}

It is observed that $\mathrm{P} \& \mathrm{O}$ conventional algorithm is based only on a single P-V or I-V characteristic curve, and all perturbations are focused on it. These perturbations have not taken into account the variations of weather. Normally, the weather variations are occurrence at least between two P-V characteristic curves [6], [13], [36]. So, the P\&O conventional algorithm should recognize the variation of the PV power between these P-V curves. The change in the PV power may increase or decrease according to weather conditions under constant load. The following steps explain the modified algorithm:

1) During perturbation $K$ suppose that, the solar irradiance is increased from $400 \mathrm{~W} / \mathrm{m}^{2}$ to $1000 \mathrm{~W} / \mathrm{m}^{2}$ under fixed load " $\mathrm{R}_{\mathrm{L}}$ ". The increasing of weather will move the operating point of PV system from point "A1" on lower I-V curve to point "B1" on upper I-V curve as shown in Fig. 8. The transferring of the operating point will increase the PV voltage from point "A1" on lower I-V curve to point "B1" on upper $\mathrm{I}-\mathrm{V}$ curve. Also, the PV power point "C1" that is located on MPP1 of lower P-V curve will change to point "D1"that is far away from MPP2 on the upper P-V curve.

2) Both increasing of PV power and voltage under constant load from lower to upper I-V and $\mathrm{P}-\mathrm{V}$ curves of Fig. 8 , will give positive change in power $\Delta \mathrm{P}>0, \Delta \mathrm{P}=\mathrm{P}(\mathrm{k})-$ 
$\mathrm{P}(\mathrm{k}-1)$ and positive change in voltage $\Delta \mathrm{V}>0, \Delta \mathrm{V}=\mathrm{V}(\mathrm{k})-\mathrm{V}(\mathrm{k}-1)$ without change in load resistance. Both positive change in power $(\Delta \mathrm{P}>0)$ and voltage $(\Delta \mathrm{V}>0)$ under constant load $\left(\Delta \mathrm{R}_{\mathrm{L}}=0\right)$ will orient algorithm to decrement voltage perturbation to obtain MPP2 of Fig. 8. MPP is the main goal of algorithm to optimize the PV power.

3) Suppose that the solar irradiance is decreased from $1000 \mathrm{~W} / \mathrm{m}^{2}$ to $400 \mathrm{~W} / \mathrm{m}^{2}$ during perturbation $\mathrm{K}+1$ of $\mathrm{P} \& \mathrm{O}$ algorithm. The reducing of irradiance level will reduce voltage level and move the operating point from point "A2" on upper I-V curve to point "B2" on lower I-V curve as shown in Fig. 8. The transferring of operating point will also decrease the PV power from point "C2" that is located on MPP2 on upper P-V curve to point "D2" that is deviated from MPP1 on lower P-V curve as illustrated of Fig. 8 on $\mathrm{P}-\mathrm{V}$ curves under fixed load with negative change in power $\Delta \mathrm{P}<0, \Delta \mathrm{P}=\mathrm{P}(\mathrm{k}+2)-\mathrm{P}(\mathrm{k}+1)$ and negative change in voltage $\Delta \mathrm{V}<$ $0, \Delta \mathrm{V}=\mathrm{V}(\mathrm{k}+2)-\mathrm{V}(\mathrm{k}+1)$. Both negative change in power $(\Delta \mathrm{P}<0)$ and voltage $(\Delta \mathrm{V}<0)$ under constant load $\left(\Delta \mathrm{R}_{\mathrm{L}}=0\right)$ will orient algorithm to increment voltage perturbation to reach MPP1 of Fig. 8. Optimizing of power is satisfied for algorithm by extracting MPP.

4) When the load is varied under constant weather condition, the conventional $\mathrm{P} \& \mathrm{O}$ algorithm will track MPP of PV system with best performance.

Therefore, the load resistance $\left(\mathrm{R}_{\mathrm{L}}\right)$ will orient the proposed $\mathrm{P} \& \mathrm{O}$ algorithm to recognize the cause of power variation which is either coming from weather or load. The combination of both weather and load change techniques, will result a modified P\&O algorithm. This algorithm can distinguish between the change in power is coming from weather or load as shown in flowchart of Fig. 9.

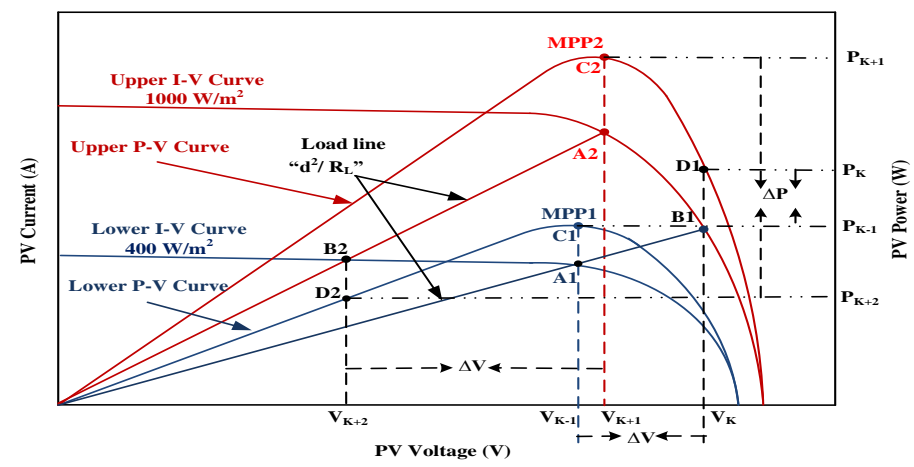

Fig. 8. PV power and voltage due to weather variations.

\subsection{Minimizing oscillations with fast tracking of MPP}

The steady state oscillations of conventional $\mathrm{P} \& \mathrm{O}$ algorithm are minimized with fast tracking of MPP. These are satisfied using a variable "d" that gives linear relation between input and output voltages [42]. This variable has an efficient effect on the duty cycle " $\mathrm{D}$ " to speed up the algorithm to track MPP. The relation between duty cycle and that variable is given from Eq. (6). From Eq. (6), it can be seen that the duty cycle has variable values with fixed change of variable $d$ as shown in Fig. 10. This figure indicates large variation of the duty cycle at lower values of $d$ and smaller variation of $D$ at higher value of $d$ which satisfied 
Montaser Abd-El Sattar, et al., A modified perturb and observe algorithm for maximum power...

the optimum requirements of extracting MPP. The change of duty cycle will reduce the oscillations at steady state. Normally, the zero value is floating point due to truncation error and cannot be determined with the precious practical manner which closely to it $[25,41]$. So, it should assume a precious value that is below it, the algorithm will fix the duty cycle to minimize steady oscillations to zero without consideration loss of PV power. To satisfy this requirement, the minimum change in power with respect to its power $(\Delta \mathrm{P} / \mathrm{P})$ is proposed less than the precious value " $\varepsilon$ ". If the change in $(\Delta \mathrm{P} / \mathrm{P})$ is less than $\varepsilon \leq 0.004$, the algorithm will fix the value of "d" and consequently the duty cycle.

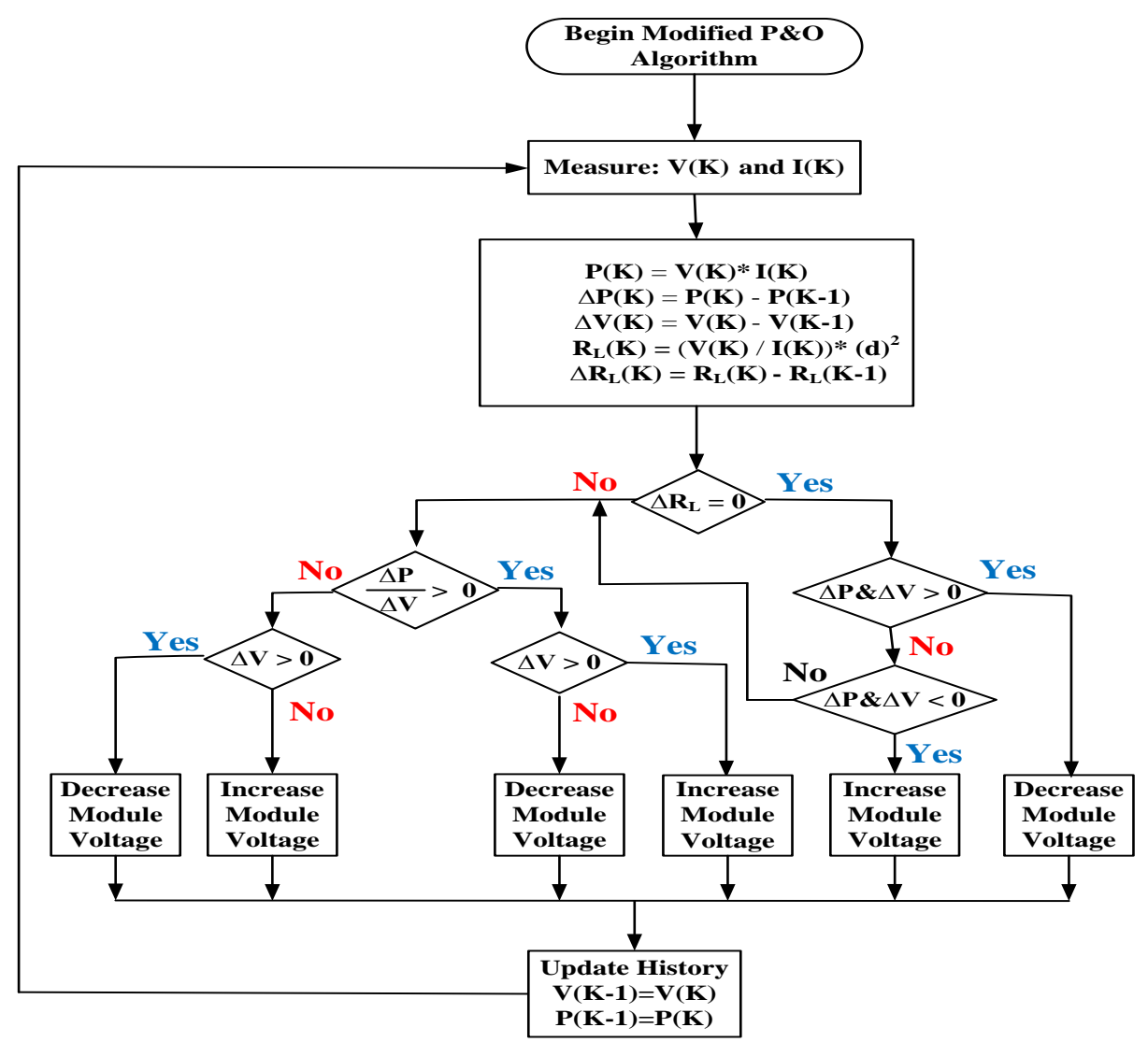

Fig. 9. Flowchart of modified $\mathrm{P} \& \mathrm{O}$ algorithm.

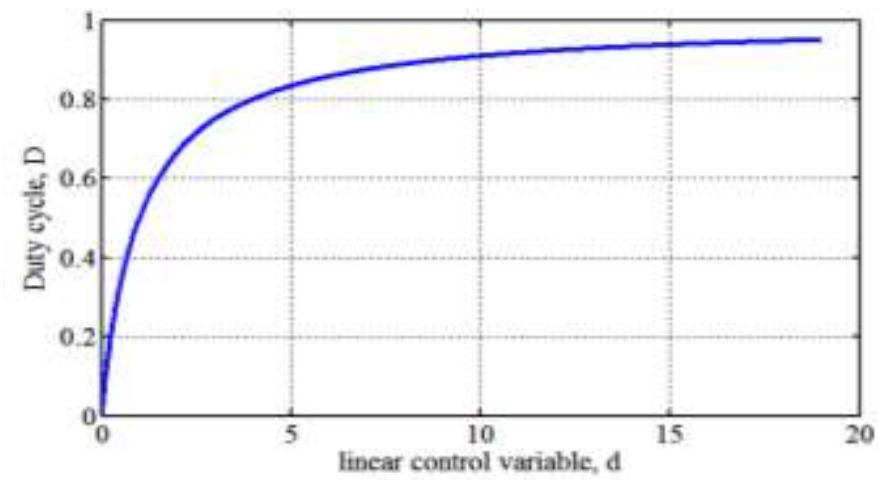

Fig. 10. Relationship between duty cycle and variable "d". 


\section{Modelling of photovoltaic module}

The current equation of the two diode-model of Fig. 11 is written as [43].

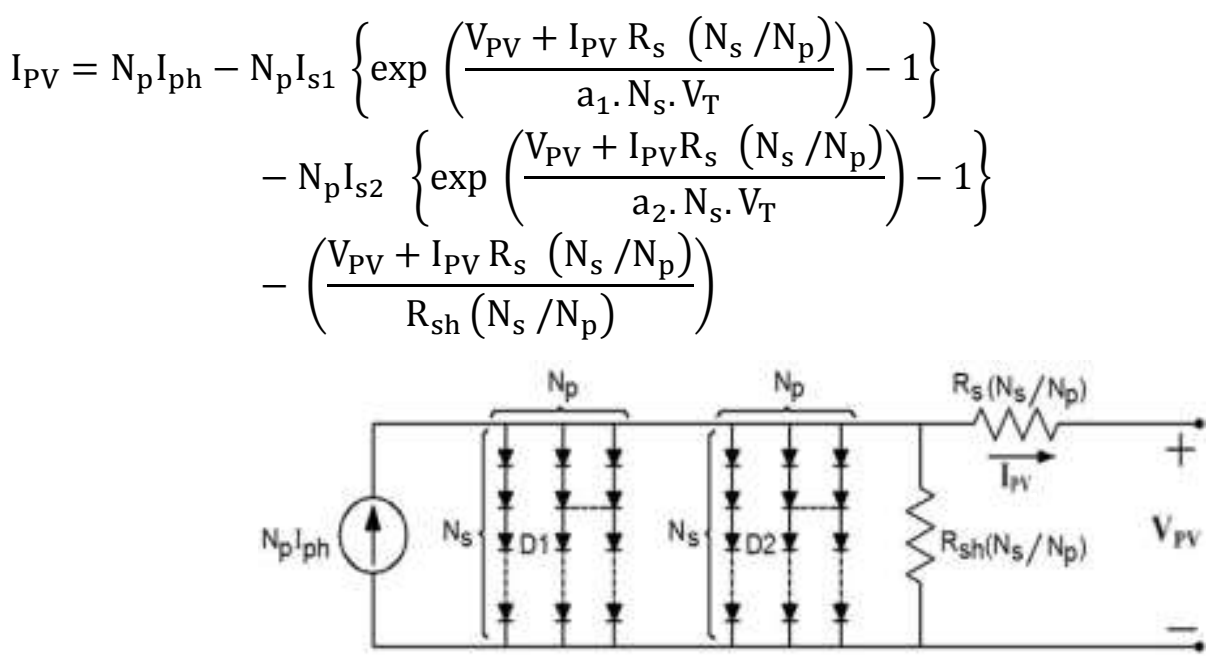

Fig. 11. Equivalent circuit model of generalized PV module [43].

Where,

$\mathrm{N}_{\mathrm{p}}$ is the number of parallel cells,

$\mathrm{N}_{\mathrm{s}}$ is the number of series solar cells,

$R_{s}$ is the series resistance of the module $(\Omega)$,

$\mathrm{R}_{\mathrm{sh}}$ is the parallel resistance of the module $(\Omega)$,

$\mathrm{V}_{\mathrm{T}}$ is the thermal voltage of the diode $(\mathrm{V}),\left(\mathrm{V}_{\mathrm{T}}=\mathrm{KT} / \mathrm{q}\right)$,

$\mathrm{a}_{1}$ and $\mathrm{a}_{2}$ are ideality factors for D1 and D2 respectively,

$\mathrm{I}_{\mathrm{pv}}$ is the output current of PV model (A),

$\mathrm{V}_{\mathrm{pv}}$ is output voltage of PV model (V),

$\mathrm{I}_{\mathrm{s} 1}$ is the diffusion saturated current of D1 (A), and

$\mathrm{I}_{\mathrm{s} 2}$ is recombination saturated current of $\mathrm{D} 2(\mathrm{~A})$.

The photo current, $\mathrm{I}_{\mathrm{ph}}$ is a function of temperature and solar irradiance is given as follows [43]:

$$
\mathrm{I}_{\mathrm{ph}}=\left(\mathrm{G} / \mathrm{G}_{\mathrm{STC}}\right)\left[\mathrm{I}_{\mathrm{ph} \text { at STC }}+\mathrm{K}_{\mathrm{i}}\left(\mathrm{T}-\mathrm{T}_{\mathrm{STC}}\right)\right]
$$

Where,

$\mathrm{G}$ is the solar irradiance $\left(\mathrm{kW} / \mathrm{m}^{2}\right)$,

$\mathrm{G}_{\mathrm{STC}}$ is the solar irradiance at standard test conditions (STC) $\left[\mathrm{G}_{\mathrm{STC}}=1 \mathrm{~kW} / \mathrm{m}^{2}\right]$,

$\mathrm{T}$ is the cell working temperature (Kelvin),

$\mathrm{T}_{\text {STC }}$ is the temperature of PV cell at STC,

$\mathrm{I}_{\mathrm{ph}}$ at STC is the photo current at STC (A)and

$\mathrm{K}_{\mathrm{i}}$ is the short circuit current coefficient $\left(\mathrm{A} / \mathrm{C}^{\circ}\right)$. 
Montaser Abd-El Sattar, et al., A modified perturb and observe algorithm for maximum power...

The two-diode saturation currents as function of working PV temperature are given as follow [43]:

$$
\begin{aligned}
& \mathrm{I}_{\mathrm{s} 1}=\mathrm{I}_{\mathrm{s} 1 \text { at } \mathrm{STC}}\left(\frac{\mathrm{T}}{\mathrm{T}_{\mathrm{STC}}}\right)^{3} \exp \left[\left(\frac{\mathrm{q} \cdot \mathrm{E}_{\mathrm{g}}}{\mathrm{a}_{1} \cdot \mathrm{K}}\right)\left(\frac{1}{\mathrm{~T}_{\mathrm{STC}}}-\frac{1}{\mathrm{~T}}\right)\right] \\
& \mathrm{I}_{\mathrm{s} 2}=\mathrm{I}_{\mathrm{s} 2 \text { at } \mathrm{STC}}\left(\frac{\mathrm{T}}{\mathrm{T}_{\mathrm{STC}}}\right)^{3} \exp \left[\left(\frac{\mathrm{q} \cdot \mathrm{E}_{\mathrm{g}}}{\mathrm{a}_{2} \cdot \mathrm{K}}\right)\left(\frac{1}{\mathrm{~T}_{\mathrm{STC}}}-\frac{1}{\mathrm{~T}}\right)\right]
\end{aligned}
$$

Where,

$\mathrm{K}$ is Boltzmann constant $\left(1.38 * 10^{-23} \mathrm{~J} /\right.$ Kelvin $)$,

$\mathrm{q}$ is electron charge $\left(1.6 * 10^{-19} \mathrm{C}\right)$ and

$\mathrm{E}_{\mathrm{g}}$ is the band gap energy of semiconductor $(\mathrm{eV})$.

The PV system is implemented in Matlab/Simulink with DC/DC buck-boost converter to obtain MPP using modified $\mathrm{P} \& \mathrm{O}$ algorithm.

\section{System Simulation and Results}

Fig. 12 shows the Matlab/Simulink simulation model of the PV system. The simulated system is composed of multi-crystalline solar modules, $\mathrm{P} \& \mathrm{O}$ proposed algorithm, DC/DC buck-boost converter and $\mathrm{R}_{\mathrm{L}}$.

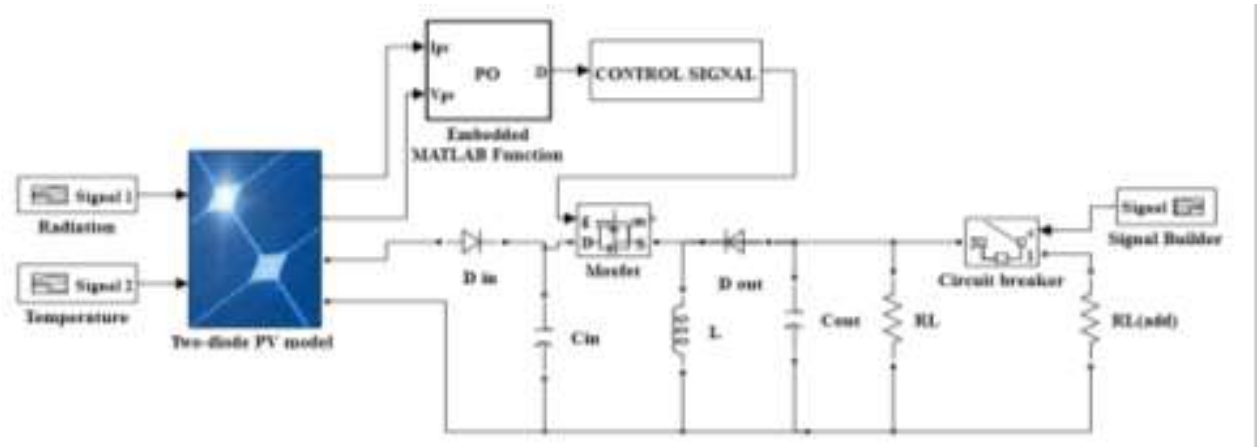

Fig. 12. PV system model on Matlab/Simulink.

The performance of the modified $\mathrm{P} \& \mathrm{O}$ algorithm is simulated for the following conditions:

\subsection{Solar irradiance variation}

The simulation model is composed of (4 MSX-60) modules connected in series [18]; each module has rated at $60 \mathrm{~W}$ to obtain total power of $240 \mathrm{~W}$ at STC. Parameters of two-diode model for (MSX-60) module and DC/DC buck-boost converter are given in Table 1 [18, 43].

The solar irradiance level is stepped from low to high and then to low again as shown in Fig. 13. The initial level is set at $\mathrm{G}=0.4 \mathrm{~kW} / \mathrm{m}^{2}$.At $\mathrm{t}=2 \mathrm{sec}$, the irradiance is suddenly stepped up to $\mathrm{G}=1.0 \mathrm{~kW} / \mathrm{m}^{2}$. Finally at $\mathrm{t}=6 \mathrm{sec}$, it is stepped down to $\mathrm{G}=0.4 \mathrm{~kW} / \mathrm{m}^{2}$. The temperature is kept constant at $25^{\circ} \mathrm{C}$ for all irradiance levels. Figs. 14-16 show the simulation results of extracted maximum power, current and voltage respectively as compared with available PSO-P\&O algorithm results of Ref. [18]. It can be seen from figures that, the modified $\mathrm{P} \& \mathrm{O}$ algorithm is more accurate, powerful and responsively than PSO-P\&O algorithm of Ref. [18]. 


\section{Table 1.}

Parameters of MSX-60 and DC/DC buck-boost converter.

\begin{tabular}{|c|c|c|c|c|c|}
\hline \multicolumn{5}{|c|}{ BP solar MSX-60 } & \multicolumn{2}{c|}{ DC/DC buck-boost converter } \\
\hline $\begin{array}{c}\text { Datasheet } \\
\text { parameter } \\
{[43]}\end{array}$ & $\begin{array}{c}\text { Parameter } \\
\text { value [43] }\end{array}$ & $\begin{array}{c}\text { Two-diode } \\
\text { model } \\
\text { parameter } \\
{[43]}\end{array}$ & $\begin{array}{c}\text { Computed } \\
\text { results [43] }\end{array}$ & $\begin{array}{c}\text { Converter } \\
\text { parameter } \\
{[18]}\end{array}$ & $\begin{array}{c}\text { Parameter value } \\
{[18]}\end{array}$ \\
\hline $\mathrm{P}_{\mathrm{mp}}, \mathrm{W}$ & 60.000 & $\mathrm{I}_{\mathrm{ph}}, \mathrm{A}$ & 3.8084 & $\mathrm{~L}, \mathrm{H}$ & $1.000 \times 10^{-3}$ \\
\hline $\mathrm{I}_{\mathrm{sc}}, \mathrm{A}$ & 3.8000 & $\mathrm{I}_{\mathrm{s} 1}, \mathrm{~A}$ & $4.8723 \times 10^{-10}$ & $\mathrm{C}_{\mathrm{in}}, \mathrm{F}$ & $470.0000 \times 10^{-6}$ \\
\hline $\mathrm{V}_{\mathrm{oc}}, \mathrm{V}$ & 21.1000 & $\mathrm{I}_{\mathrm{s} 2}, \mathrm{~A}$ & $6.1528 \times 10^{-10}$ & $\mathrm{C}_{\mathrm{out}}, \mathrm{F}$ & $220.0000 \times 10^{-6}$ \\
\hline $\mathrm{I}_{\mathrm{mp}}, \mathrm{A}$ & 3.5000 & $\mathrm{R}_{\mathrm{s}}, \Omega$ & 0.3692 & $f, \mathrm{~Hz}$ & $50.000 \times 10^{3}$ \\
\hline $\mathrm{V}_{\mathrm{mp}}, \mathrm{V}$ & 17.1000 & $\mathrm{R}_{\mathrm{sh}}, \Omega$ & 169.0471 & $\mathrm{R}_{\mathrm{L}}, \Omega$ & 50 \\
\hline $\mathrm{K}_{\mathrm{V}}, \mathrm{V} / \mathrm{C}^{\circ}$ & $-80.0000 \times 10^{-3}$ & $\mathrm{a}_{1}$ & 1.0003 & & \\
\hline $\mathrm{K}_{\mathrm{i}}, \mathrm{A} / \mathrm{C}^{\circ}$ & $3.000 \times 10^{-3}$ & $\mathrm{a}_{2}$ & 1.9997 & & \\
\hline $\mathrm{N}_{\mathrm{s}}$ & 36.000 & & & & \\
\hline $\mathrm{N}_{\mathrm{p}}$ & 1.000 & & & & \\
\hline
\end{tabular}

The tracking efficiency of the proposed algorithm can be calculated from the following equation:

$$
\eta=P_{\text {extracted }} / P_{\text {calculated }}
$$

Where: $\mathrm{P}_{\text {extracted }}$ is the maximum extracted power at certain irradiance and temperature. $\mathrm{P}_{\text {calculated }}$ is the maximum power from manufacturing data sheet at certain irradiance and temperature.

At STC: $\quad \mathrm{P}_{\text {extracted }}$ of series modules $(\mathrm{MSX}-60)=237.6 \mathrm{~W}$ as shown in Fig. 14.

$\mathrm{P}_{\text {calculated }}=$ maximum power of module*number of modules $=60 * 4=240 \mathrm{~W}$ as shown in Table 1 .

Proposed algorithm efficiency $=(237.6 / 240) * 100=99.125 \%$.

From the obtained results, it can be seen that the proposed algorithm is extracted maximum power with high efficiency (99.125\%) and response without oscillation. Obtained efficiency from proposed algorithm is greater than the efficiency of the conventional $\mathrm{P} \& \mathrm{O}$ algorithm which is normally about $96.5 \%$ [2].

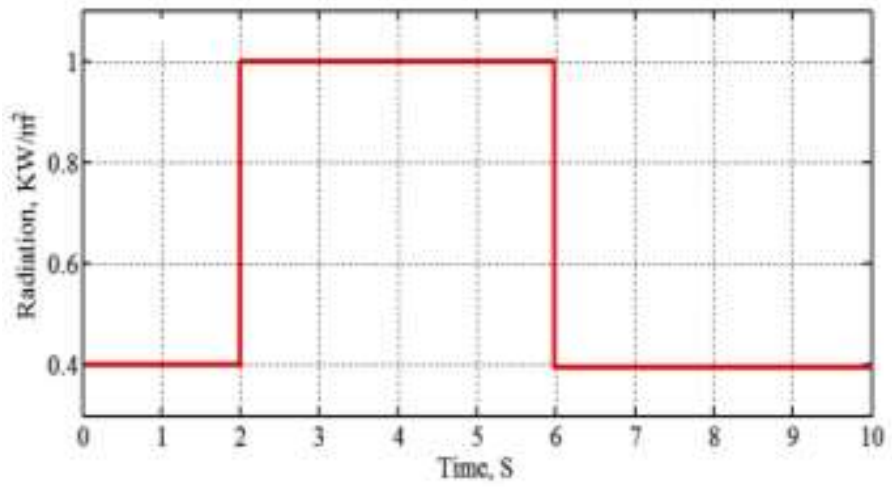

Fig. 13. Variation of solar irradiance. 


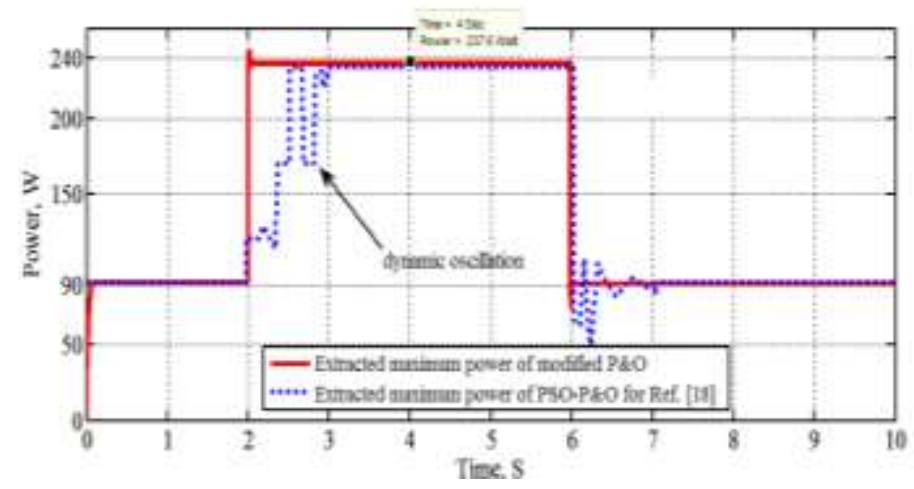

Fig. 14. PV system power compared to results of Ref. [18] during irradiance change.

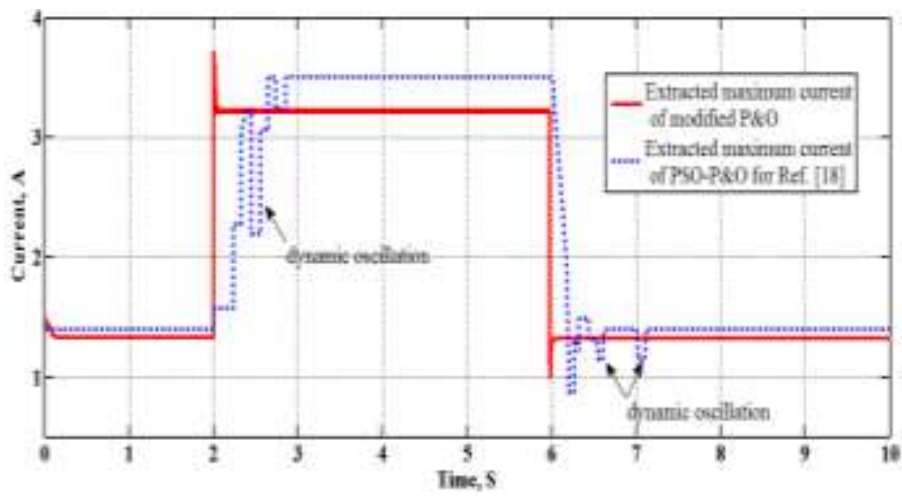

Fig. 15. PV system current compared to results of Ref. [18] during irradiance change.

\subsection{Load variation}

Fig. 17 shows the maximum output power by the proposed $\mathrm{P} \& \mathrm{O}$ algorithm as compared with PSO-P\&O algorithm of Ref. [18] during load variation. Under standard conditions $\left(1000 \mathrm{~W} / \mathrm{m}^{2}, 25^{\circ} \mathrm{C}\right)$, the output PV system is $240 \mathrm{~W}$. At $\mathrm{t}=2 \mathrm{Sec}$., a $50 \%$ step change in load is imposed (inserting additional resistor $\mathrm{R}_{\mathrm{L}(\text { add) }}$ of $100 \Omega$ in parallel with load resistor $\mathrm{R}_{\mathrm{L}}$ of $50 \Omega$ using circuit breaker as shown in Fig. 12, causing a sudden drop in the PV power. Then, the modified P\&O algorithm is forced to track the MPP for the new load condition. From this figure it can be seen that, quick response with minimum oscillation of the modified P\&O algorithm as compared with PSO-P\&O modified algorithm of Ref. [18].

\subsection{Temperature variation}

The whole PV system model with its associated DC/DC buck-boost converter which consists of 36 cells and modified $\mathrm{P} \& \mathrm{O}$ algorithm is shown in Fig. 12. The solar cells parameters are given in Table 2 [8], also, the estimated parameters of two-diode model and DC/DC buck-boost converter are given in Table 2 . 


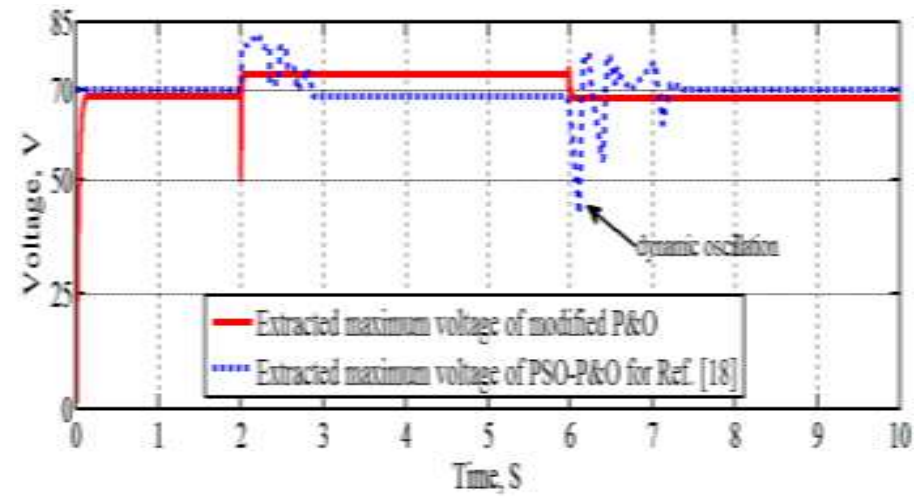

Fig. 16. PV system voltage compared to results of Ref. [18] during irradiance change.

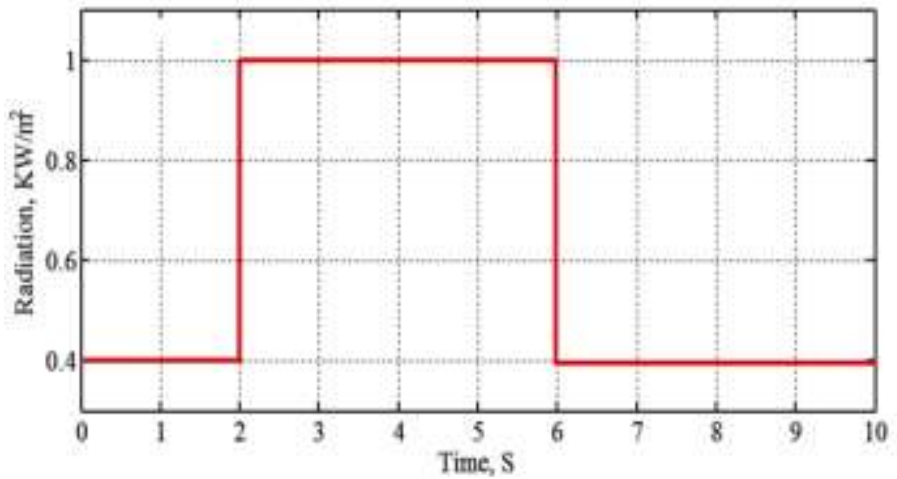

Fig. 17. PV system power compared to results of Ref. [18] during load change.

The PV system is subjected to temperature variations under constant irradiance at $1000 \mathrm{~W} / \mathrm{m}^{2}$ as follow:

The PV system temperature is stepped from high to low and then again to high with linearly increasing up to $50^{\circ} \mathrm{C}$ as shown in Fig. 18. The initial temperature value is set at $\mathrm{T}=25^{\circ} \mathrm{C}$. At time equal to $3 \mathrm{sec}$, the temperature is suddenly stepped down to $\mathrm{T}=10^{\circ} \mathrm{C}$. Then at time equal to $5 \mathrm{sec}$, it is stepped up to $\mathrm{T}=25^{\circ} \mathrm{C}$. The temperature is kept constant at $25^{\circ} \mathrm{C}$ up to $6 \mathrm{sec}$. After that the temperature is linearly increased from $25^{\circ} \mathrm{C}$ to $50^{\circ} \mathrm{C}$ during time period starting from $6 \mathrm{sec}$ up to $9 \mathrm{sec}$. Finally the PV system temperature stills constant at $50^{\circ} \mathrm{C}$.

Figs. 19-20 show the simulation results of both power, and voltage as compared with the experimental results of incremental conductance algorithm of Ref. [8]. These figures illustrate that the modified algorithm is more accurate, powerful, and responsively than incremental conductance algorithm experimental results of Ref. [8]. Also, these figures indicate large oscillation of voltages using incremental conductance algorithm around MPP as compared to modified $\mathrm{P} \& \mathrm{O}$ proposed algorithm. 
Montaser Abd-El Sattar, et al., A modified perturb and observe algorithm for maximum power...

\section{Table 2.}

Parameters of solar module and DC/DC buck-boost converter.

\begin{tabular}{|c|c|c|c|c|c|}
\hline \multicolumn{5}{|c|}{ Solar cell module parameters } & \multicolumn{2}{c|}{ DC/DC buck-boost converter } \\
\hline $\begin{array}{c}\text { Datasheet } \\
\text { parameter }\end{array}$ & $\begin{array}{c}\text { Parameter } \\
\text { value }[8]\end{array}$ & $\begin{array}{c}\text { Two diode } \\
\text { model } \\
\text { parameter }\end{array}$ & $\begin{array}{c}\text { Computed } \\
\text { results }\end{array}$ & $\begin{array}{c}\text { Converter } \\
\text { parameter }\end{array}$ & Parameter value \\
\hline $\mathrm{P}_{\mathrm{mp}}, \mathrm{W}$ & 63.0000 & $\mathrm{I}_{\mathrm{ph}}, \mathrm{A}$ & 3.3001 & $\mathrm{~L}_{\mathrm{f}}, \mathrm{H}$ & $1.5000 \times 10^{-3}$ \\
\hline $\mathrm{I}_{\mathrm{sc}}, \mathrm{A}$ & 3.3000 & $\mathrm{I}_{\mathrm{s} 1}, \mathrm{~A}$ & $1.4767 \times 10^{-11}$ & $\mathrm{~L}, \mathrm{H}$ & $85.0000 \times 10^{-6}$ \\
\hline $\mathrm{V}_{\mathrm{oc}}, \mathrm{V}$ & 25.0000 & $\mathrm{I}_{\mathrm{s} 2}, \mathrm{~A}$ & $1.26688 \times 10^{-6}$ & $\mathrm{C}_{\mathrm{f}}, \mathrm{F}$ & $200.0000 \times 10^{-6}$ \\
\hline $\mathrm{I}_{\mathrm{mp}}, \mathrm{A}$ & 3.1000 & $\mathrm{R}_{\mathrm{s}}, \Omega$ & 0.1981 & $\mathrm{C}_{\mathrm{out}}, \mathrm{F}$ & $100.0000 \times 10^{-6}$ \\
\hline $\mathrm{V}_{\mathrm{mp}}, \mathrm{V}$ & 20.3000 & $\mathrm{R}_{\mathrm{sh}}, \Omega$ & $1.0196 \times 10^{3}$ & $\mathrm{f}, \mathrm{Hz}$ & $50.0000 \times 10^{3}$ \\
\hline $\mathrm{K}_{\mathrm{v}}, \mathrm{V} / \mathrm{C}^{\circ}$ & $-80.000 \times 10^{-3}$ & $\mathrm{a}_{1}$ & 1.0000 & & \\
\hline $\mathrm{K}_{\mathrm{i}}, \mathrm{A} / \mathrm{C}^{\circ}$ & $3.0000 \times 10^{-3}$ & $\mathrm{a}_{2}$ & 2.0000 & & \\
\hline $\mathrm{N}_{\mathrm{s}}$ & 36 & & & & \\
\hline $\mathrm{N}_{\mathrm{p}}$ & 1 & & & & \\
\hline
\end{tabular}

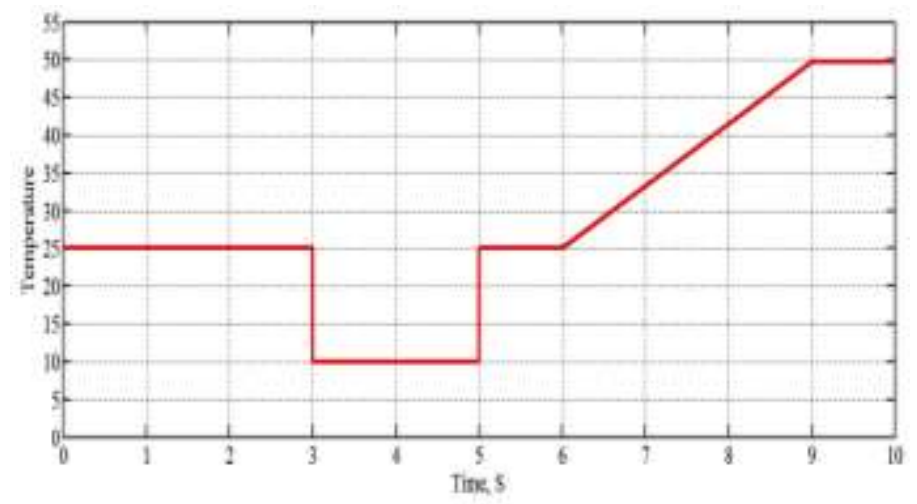

Fig. 18. Diagram of temperature variation of the PV system for Ref. [8]

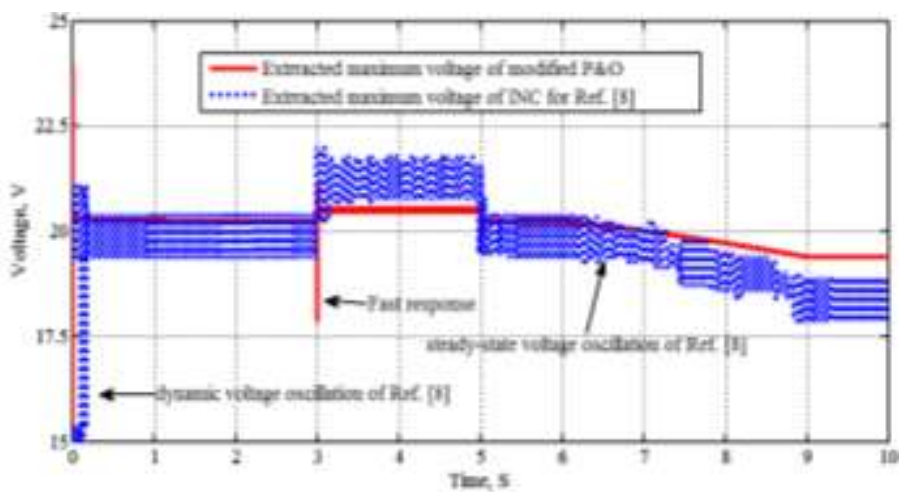

Fig. 19. PV system power compared to results of Ref. [8] during temperature change. 


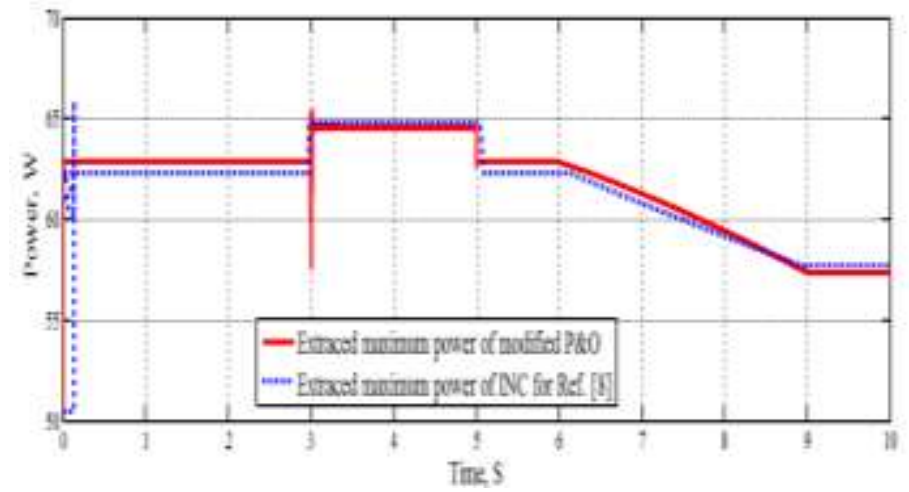

Fig. 20. PV system voltage compared to results of Ref. [8] during temperature change.

\section{Conclusions}

Maximum power point tracking techniques extract the maximum output power of the PV systems at certain weather conditions to maximize its efficiency and minimize the overall system cost. Unfortunately, MPPT techniques deviate from MPP location as a result of weather or load variations. The most conventional and popular technique is $\mathrm{P} \& \mathrm{O}$ algorithm due to its simplicity, costless and has minimum controlled parameters. The conventional $\mathrm{P} \& \mathrm{O}$ algorithm has many drawbacks such as failure to extract MPP during rapid change of weather, oscillations around the MPP and instabilities. In this paper, a new modified $\mathrm{P} \& \mathrm{O}$ algorithm is proposed to enhance the conventional $\mathrm{P} \& \mathrm{O}$ algorithm for overcoming previously drawbacks. This proposed algorithm is based on load technique to enable conventional $\mathrm{P} \& \mathrm{O}$ algorithm to recognize the cause of power change either is coming from weather or load change. The results of proposed $\mathrm{P} \& \mathrm{O}$ algorithm show good excellent maximum power tracking due to rapid variations in weather or load as compared with simulation and experimental previous research works. The modified proposed $\mathrm{P} \& \mathrm{O}$ algorithm satisfies extracting maximum power with high efficiency due to rapid change of weather, minimizing the oscillations around MPP, giving quick and high response, and finally increasing stability of PV system. This paper provided a clear, accurate, and practical powerful tool for MPP field applications.

\section{REFERENCES}

[1] M. Killi, and S. Samanta, "Modified Perturb and Observe MPPT Algorithm for Drift Avoidance in Photovoltaic Systems," IEEE Trans. Industrial Electron., Vol. PP, No. 99, pp. 1-10, 2015.

[2] S. K. Kollimalla, and M. K. Mishra, "Adaptive Perturb \& Observe MPPT Algorithm for Photovoltaic System", 2013 IEEE Power and Energy Conference at Illinois (PECI), pp. 42-47, 2013.

[3]R. Rawat, and S. Handel, "Hill Climbing Techniques for Tracking Maximum Power Point in Solar Photovoltaic Systems-A Review," Special Issue of Int. J. Sustainable Develop. Green Economics (IJSDGE), Vol. 2, pp. 90-95, 2013.

[4]A. Safari, and S. Mekhilef, "Simulation and hardware implementation of incremental conductance MPPT with direct control method using cuk converter", IEEE Trans. Industrial Electron. Vol. 58, No. 4, pp. 1154-1161, 2011.

[5]R. Faranda, and S. Leva, "Energy Comparison of MPPT Techniques for PV Systems", WSEAS Trans. Power Systems Vol. 3, No. 6, pp. 446-455, 2008. 
[6]A. Nasr Allah, M. Saied, M. Mustafa, and T. Abdel-Moneim, "A Survey of Maximum PPT techniques of PV Systems, Browse Conference Publications”, Energytech, IEEE, pp. 1-17, 2012.

[7]Joe-Air Jiang, Tsong-Liang Huang, Ying-Tung Hsiao, and Chia-Hong Chen, "Maximum Power Tracking for Photovoltaic Power Systems", Tamkang J. Sci. Eng. Vol. 8, pp. 147-153, 2005.

[8]A. Zegaoui1, M. Aillerie, P. Petit, J.P. Sawicki, A. Jaafar, C. Salame, and J.P. Charles, "Comparison of Two Common Maximum Power Point Trackers by Simulating of PV Generators, Energy Procedia, Vol. 6 ,pp. 678-687, 2011.

[9]A. Swathy and R. Archana, "Maximum Power Point Tracking Using Modified Incremental Conductance for Solar Photovoltaic System, Int. J. Eng. Innovative Technol. (IJEIT), Vol. 3, No. 2, pp. 333-337, 2013.

[10] E. Solodovnik, L. Shengyi, and R. Dougal, "Power Controller Design for Maximum Power Tracking in Solar Installations, IEEE Trans. Power Electron.” Vol. 19, pp. 1295-1304, 2004.

[11] M. A. S. Masoum, H. Dehbonei, and E. F. Fuchs, "Theoretical and experimental analyses of photovoltaic systems with voltage and current based maximum power-point tracking," IEEE Trans. Energy Convers., Vol. 17, No. 4, pp. 514-522, Dec. 2002.

[12] W. Xiao, and W. G. Dunford, "A modified adaptive Hill Climbing MPPT Method for Photovoltaic Power Systems,” in Proc. IEEE PESC, pp. 1957-1963, 2004.

[13] N. Femia, G. Petrone, G. Spagnuolo, and M. Vitelli, "Optimization of perturb and observe maximum power point tracking method," IEEE Trans. Power Electron., Vol. 20, No. 4, pp. 963-973, Jul. 2005.

[14] N. Femia, D. Granozio, G. Petrone, G. Spagnuolo, and M. Vitelli, "Predictive and Adaptive MPPT Perturb and Observe Method," IEEE Trans. Aerosp. Electron. Syst., Vol. 43, No. 3, pp. 934-950, Jul. 2007.

[15] D. Sera, R. Teodorescu, J. Hantschel, and M. Knoll, "Optimized maximum power point tracker for fast-changing environmental conditions," IEEE Trans. Ind. Electron., Vol. 55, No. 7, pp. 2629-2637, Jul. 2008.

[16] A. Pandey, N. Dasgupta, and A. K. Mukerjee, "High-performance algorithms for drift avoidance and fast tracking in solar MPPT system," IEEE Trans. Energy Convers., Vol. 23, No. 2, pp. 681-689, Jun. 2008.

[17] L. Piegari, and R. Rizzo, "Adaptive perturb and observe algorithm for photovoltaic maximum power point tracking," IET Renewable Power Generation, Vol. 4, No. 4, pp. 317-328, Jul. 2010.

[18] K. Ishaque, Z. Salam, M. Amjad, and S. Mekhilef, "An Improved Particle Swarm Optimization (PSO)-Based MPPT for PV with Reducing Steady-State Oscillation," IEEE Trans. Power Electron. Vol. 27, No. 8, pp. 3627-3638, 2012.

[19] Y. Jiang, J. A. A. Qahouq, and T. A. Haskew, "Adaptive step size with adaptiveperturbation-frequency digital MPPT controller for a single sensor photovoltaic solar system,” IEEE Trans. Power Electron., Vol. 28, No. 7, pp. 3195-3205, Jul. 2013.

[20] K. L. Lian, J. H. Jhang, and I. S. Tian, "A maximum power point tracking method based on perturb-and-observe combined with particle swarm optimization," IEEE J. of Photovoltaics, Vol. 4, No. 2, pp. 626-633, Mar. 2014.

[21] F. Liu, S. Duan, B. Liu, and Y. Kang, "A variable step size INC MPPT method for PV systems,” IEEE Trans. Ind. Electron., Vol. 55, No. 7, pp. 2622-2628, Jul. 2008.

[22] S. B. Kjaer, "Evaluation of the hill climbing and the incremental conductance maximum power point trackers for photovoltaic power systems," IEEE Trans. Energy Convers., Vol. 27, No. 4, pp. 922-929, Dec. 2012.

[23] M. A. Algendy, B. Zahawi, and D. J. Atkinson, "Assessment of the incremental conductance maximum power point tracking algorithm," IEEE Trans. Sustain. Energy, Vol. 4, No. 1, pp. 108-117, Jan. 2013.

[24] G. C. Hsieh, H. I. Hsieh, C. Y. Tsai, and C. H. Wang, "Photovoltaic power-increment-aided incremental-conductance MPPT with two-phased tracking," IEEE Trans. Power Electron., Vol. 28, No. 6, pp. 2895-2911, Jun. 2013. 
[25] K. S. Tey, and S. Mekhilef, "Modified incremental conductance algorithm for photovoltaic system under partial shading conditions and load variation," IEEE Trans. Ind. Electron., Vol. 61, No. 10, pp. 5384-5392, Oct. 2014.

[26] Q. Mei, M. Shan, L. Liu, and J. M. Guerrero, "A novel improved variable step-size incremental- resistance MPPT method for PV systems," IEEE Trans. Ind. Electron., Vol. 58, No. 6, pp. 2427-2434, Jun. 2011.

[27] T. Esram, J. W. Kimball, P. T. Krein, P. L. Chapman, and P. Midya, "Dynamic maximum power point tracking of photovoltaic arrays using ripple correlation control," IEEE Trans. Power Electron., Vol. 21, No. 5, pp. 1282-1291, Sep. 2006.

[28] A. A. Nabulsi, and R. Dhaouadi, "Efficiency optimization of a dsp-based standalone pv system using fuzzy logic and dual-mppt control,” IEEE Trans. Ind. Informat., Vol. 8, No. 3, pp. 573-584, Aug. 2012.

[29] Syafaruddin, E. Karatepe, and T. Hiyama, "Artificial neural network polar coordinated fuzzy controller based maximum power point tracking control under partially shaded conditions," IET, Renew. Power Gener., Vol. 3, No. 2, pp. 239-253, Jun. 2009.

[30] K. Ishaque, and Z. Salam, "A deterministic particle swarm optimization maximum power point tracker for photovoltaic system under partial shading condition," IEEE Trans. Ind. Electron., Vol. 60, No. 8, pp. 3195-3206, Aug. 2013.

[31] H. Renaudineau, F. Donatantonio, J. Fontchastagner, G. Petrone, G. Spagnuolo, J.-P. Martin, and S. Pierfederici, "A PSO-based global MPPT technique for distributed PV power generation,” IEEE Trans. Ind. Electron., Vol. 62, No. 2, pp. 1047-1058, Feb. 2015.

[32] E. Bianconi, J. Calvente, R. Giral, E. Mamarelis, G. Petrone, C. A. Ramos-Paja, G. Spagnuolo, and M. Vitelli, "A fast current-based MPPT technique employing sliding mode control,” IEEE Trans. Ind. Electron., Vol. 60, No. 3, pp. 1168-1178, Mar. 2013.

[33] E. Mamarelis, G. Petrone, and G. Spagnuolo, "Design of a sliding mode controlled SEPIC for PV MPPT applications,” IEEE Trans. Ind. Electron., Vol. 61, No. 7, pp. 3387-3398, Jul. 2014.

[34] D. P. Hohm, and M. E. Ropp, "Comparative study of maximum power point tracking algorithms," Progress. Photovoltaics: Res. Appl., Vol. 11, pp. 47-62, Apr. 2003.

[35] V. Salas, E. Olias, A. Barrado, and A. Lazaro, "Review of the maximum power point tracking algorithms for stand-alone photovoltaic systems," Sol. Energy Mater. Sol. Cells, Vol. 90, No. 11, pp. 1555-1578, Jul. 2006.

[36] T. Esram, and P. L. Chapman, "Comparison of photovoltaic array maximum power point tracking techniques," IEEE Trans. Energy Convers., Vol. 22, No. 2, pp. 439-449, Jun. 2007.

[37] M. A. G. de Brito, L. Galotto, L. P. Sampaio, G. A. e Melo, and C. A. Canesin, "Evaluation of the main mppt techniques for photovoltaic applications," IEEE Trans. Ind. Electron., Vol. 60, No. 3, pp. 1156-1167, Mar. 2013.

[38] Salim Abouda, Frederic Nollet, Najib Essounbouli, Abdessattar Chaari, and Yassine Koubaa, Design, Simulation and Voltage Control of Standalone Photovoltaic System Based MPPT: Application to a Pumping System, Int. J. Renew. Energy Res. Vol. 3, pp. 538-549, 2013.

[39] Y. T. Tan, D. S. Kirschen, and N. Jenkins, "A model of PV generation suitable for stability analysis,” IEEE Trans. Energy Convers., Vol. 19, No. 4, pp. 748-755, Dec. 2004.

[40] D. Sera, T. Kerekes, R. Teodorescu, and F. Blaabjerg, "Improved MPPT Algorithms for Rapidly Changing Environmental Conditions", 12th International Power Electronics and Motion Control Conference, pp. 1614-1619, 2006.

[41] M. Alqarni, and M. K Darwish, "Maximum Power Point Tracking for Photovoltaic system: Modified Perturb and Observe Algorithm," $201247^{\text {th }}$ IEEE International Universities Power Engineering Conference (UPEC), pp. 1-4, 2012.

[42] D. Peftitsis, G. Adamidis and A. Balouktsis, "An investigation of new control method for MPPT in PV array using DC/DC buck - boost converter, 2nd WSEAS/IASME International Conference on Renewable Energy Sources (RES'08) Corfu, Greece, pp. 40-45, 2008.

[43] Adel A. Elbaset, Hamdi Ali and Montaser Abd-El Sattar, "Novel seven-parameter model for photovoltaic modules," Sol. Energy Mater. Sol. Cells, Vol. 130, pp. 442-455, 2014. 
تعديل خوارزمية الملاحظة والقياس لتتبع أقصى نقطة قدرة

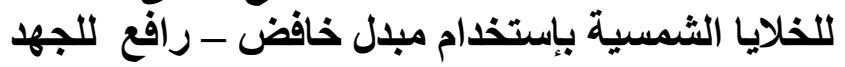

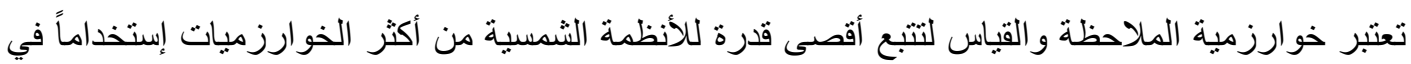

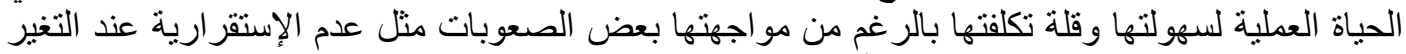
السريع للطقس وتذبذب الخوارزمية حول أقصى نقطة للقدرة عند الحالة المستقرة.

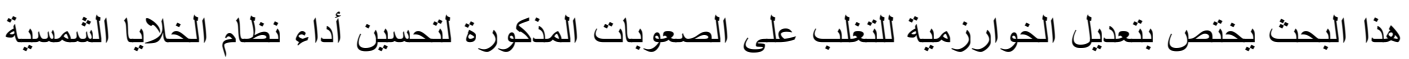

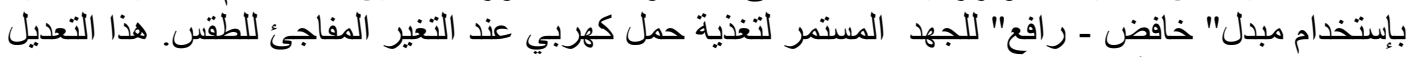

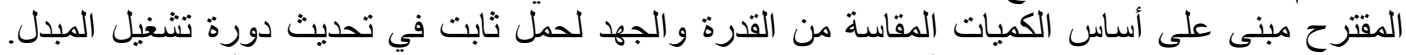

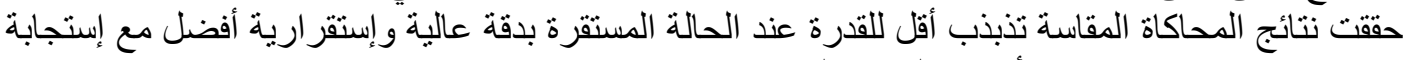
ديناميكية سريعة مقارنة مع الأبحاث السابقة المنشورة. 